\author{
Justyna E. Kulikowska-Kulesza \\ University of Bialystok \\ e-mail: j.kulikowska@uwb.edu.pl \\ ORCID: 0000-0001-6934-9014
}

\title{
INTERPRETATION OF THE RIGHT TO PRIVACY FROM THE PERSPECTIVE OF THE USE OF NEW TECHNOLOGIES
}

\begin{abstract}
Today's reality, largely based on the development of technology, carries with it many dangers for various spheres of our lives. One of the areas most at risk is our privacyand thus our right to privacy. It is one of the fundamental human rights, but unfortunately today it is exposed to many violations. This article is an attempt to interpret the right to privacy, and it shows selected threats to this right from the perspective of the development of new technologies.

Keywords: privacy, right to privacy, new technologies, monitoring, Big Data.
\end{abstract}

\section{Introduction}

Everyone needs a place - a sphere that is just for them. There are aspects of life that we want to keep only to ourselves or share them only with our loved ones. However, this sphere of life, which should be private and thus free of any external interference, is increasingly shrinking. This process has been observed over recent years. Until a few decades ago, our privacy was actually threatened only by nosey neighbours or by an over-inquisitive official. Today, our privacy is already being attacked by a completely different, more dangerous "enemy", i.e. technological development, which has created instruments and tools to make information easier to obtain. To make matters worse, it is not only about acquiring "blank" personal data, such as name or surname, or a personal identification number (PESEL).

Today's technology enables the collection of information on, e.g. our work, family, interests, leisure activities, religion and even our health. All kinds of databases, continuously monitor everyone, record phone calls, and have a far-reaching ability to locate - these are just initial instruments the technological development has brought so far. Going further, it is enough to point out, for example, various types of chips recorded by special systems 
whenever used; biometric readers or digital traces left by every person using the Internet (Weber, 2004: 24). In addition, technological development has also made us share our privacy with others far more willingly. Applications such as Facebook, Instagram and Twitter, for example, makeyour life easily accessible to others. It is surprising to what extent users are able to "let" strangers into their private spheres of life.

As the results of the research show, it can already be said without any doubt that we as a society are surveilled. It is worth noting the Report of the Panoptykon Foundation "Supervision 2011", which already in 2011 stated that "(...) a consequence of the development of the surveilled society is to limit the privacy of individuals, their information autonomy and the secrecy of correspondence (...) Surveillance may also involve restrictions on the freedom of speech or the right to information, and thus lead to a widening of the information gap: the state and corporations know more and more about us, we know less and less about them (...)". This surveillance is carried out by collecting and processing information on individuals. The most common justification for such practices is that they are carried out in the public interest, such as monitoring to ensure security and public order.

Undoubtedly, modern technological development has had a significant impact on shrinking the so-called private sphere. In most cases, an average citizen is not even aware of how much his or her life is being surveilled. The consequence of the direction "taken" by technological development is the justified danger of restricting the right to individuals' privacy.

So what is privacy? How should the right to privacy be interpreted? How is the right to privacy regulated? What is its scope? What is the relationship between the right to privacy and exemplary uses of new technologies? The analysis of the subject matter should provoke such questions and the main purpose of the paper is an attempt to answer them.

\section{Privacy}

As initially mentioned, everyone has a sphere they define as privacy. Therefore, it is an area free of any external interference, personal property, not subject to the state or any public institutions; it is about personal and family affairs. The term privacy is very often used in everyday language, but it is difficult to indicate one definition or meaning. The concept of privacy has strong historical roots, such as the well-known Aristotelian distinction between the public sphere of political activity and the private sphere related to personal life and family. 
The modern debate on privacy became most evident in the second half of the twentieth century and had a profound impact on the development of legal privacy protection. Most theoreticians indicate that the concept of privacy is highly significant and valuable. Some highlighted privacy as focused on controlling information about ourselves (see also: Parent, 1983: 269-288), while others put emphasis on a broader perspective of the issue as closely related to the notion of human dignity (see also: Bloustein, 1964: 962-1007). There is also a concept in the literature which emphasises the importance of privacy as a necessary phenomenon for the development of the diverse and significant human relations (see also: Fried, 1968: 475-493). Privacy is also defined as a set of standards and norms necessary to control information accessibility but also to increase personal expression and choice (see also: Schoeman, 1992: 52-63). In this respect the literature shows that, despite more than a century of tradition in using the concept of privacy, there is no real consensus in the doctrine, neither on its limits nor on its content. It is worth referringto the work of F.D. Schoeman, who collected and presented over a dozen of the most famous works that set directions in this respect.

After years of intense discussion, the definitions of privacy have been put in order and divided into four basic types. Namely, privacy as the right to be left alone; privacy as the right to control information about oneself; privacy as a control of access to a person; and privacy as the autonomy of an individual.

The so-called reductionist approach to privacy should be added to this catalogue (Jagielski, 2010: 23). Privacy as the right to be left alone is one of the oldest definitions of privacy. It first appeared in literature as early as the nineteenth century. It was popularised by the famous article by S. Warren and L. Brandeis. Despite widespread criticism, this definition is cited to this day. Critics pointed out that presenting privacy as the right to be left alone is, first of all, too broad in scope, because it could actually be regarded as a synonym for freedom. On the other hand, it has been pointed out that it is too narrow, because it does not cover so-called 'information privacy'. Privacy as the right to control information about oneself (known as information privacy) is nothing more than the right to decide when, how and to what extent information is to or can be communicated to others (Jagielski, 2010: 23). Privacy presented as access control to a person emphasises accessibility not only in an informative sense, but above all, in relation to a person'sself in a physical sense, creating individual spheres of life that are more or less accessible to external entities (Jagielski, 2010: 24). Privacy as the autonomy of an individual is understood as a phenomenon 
which not only guarantees the absence of external interference but also gives the individual freedom to make decisions. The reductionist approach, on the other hand, assumes that privacy as a legal category is superfluous - privacy can be reduced to the emergence of specific rights for an individual and the concept itself may be eliminated from legal language (Jagielski, 2010: 24), by referring to concepts already established in the doctrine, such as personal integrity, protection of the confidentiality of correspondence, and protection of a good reputation.

Nowadays, privacy is being examined on many levels. The concept is also divided into strict and open privacy. In Polish literature such a division was introduced by Z. Zalewski. The former includes intimacy and states, features or processes that should only be known to the individual. The latter includes everything that is available to others, i.e. extracts of private space or views and opinions shared in public (Zalewski, 2001: 96). Psychologically considering the sense of privacy, two concepts occupy a special place - Altman's Private Regulation Theory (PRT) and O'Connor and Rosenblood's Social Affiliation Model (SAM).

It can therefore be recognised that privacy as a right is fundamental. It is absolutely essential for maintaining autonomy and protecting human dignity. Simultaneously, it is the basis for many other human rights and enables the creation and the management of limits and borders protecting individuals from unjustified interference in their lives.

\section{Regulations concerning the right to privacy}

The right to privacy in its broadest sense, including family life, domestic peace, secrecy of correspondence, respect for human rights, personal integrity and the protection of personal data, is regulated in many acts both of international and national law.

The right to privacy is undoubtedly one of the fundamental rights and human freedoms. The fundamental significance of this law is confirmed, for example, by the importance of the legal acts in which it is expressed. Preliminarily, Article 12 of the Universal Declaration of Human Rights should be pointed out, which states that "no one shall be subjected to arbitrary interference with their privacy, family, home or correspondence, nor to attacks upon their honour and reputation. Everyone has the right to the protection of the law against such interference or attacks." Article 17 of the Inter-

national Covenant on Civil and Political Rights should then be indicated. It states that "no one shall be subjected to arbitrary or unlawful interfer- 
ence with their privacy, family, home or correspondence, nor to unlawful attacks on their honour and reputation" and that "everyone has the right to the protection of the law against such interference and attacks".

Unquestionably, the European Convention for the Protection of $\mathrm{Hu}-$ man Rights and Fundamental Freedoms (thereinafter ECHR) should also be mentioned as an essential act in the international legal order, because apart from defining human rights and freedoms themselves, the Convention has created one of the most effective systems for their protection in the whole world. Article 8 of the Convention includes everyone's right to respect their private and family life, their home and their correspondence. In paragraph 2, the Convention limits interference into the right in question and allows it only "in accordance with the law and necessary in a democratic society in the interests of national security, public safety or the economic wellbeing of the country, for the prevention of disorder or crime, for the protection of health or morals, or for the protection of the rights and freedoms of others".

A perfect reflection of Article 8 of the European Convention for the Protection of Human Rights and Fundamental Freedoms is found in Article 7 of the Charter of Fundamental Rights of the European Union, which states that "everyone has the right to respect their private and family life, home and communications". The absolutely fundamental significance of protecting the right to privacy is also demonstrated by the very rich and extensive case-law of the European Court of Human Rights.One of the very wellknown cases pending before the European Court of Human Rights from our country was that of Alicja Tysiąc's complaint against the Republic of Poland, which accused the state of violating a number of provisions of the Convention, including violations of its right to privacy. In the end, the complaint was considered, by a six-to-one ratio, to be a violation of Article 8 ECHR.

In the Polish legal system, Article 47 of the Constitution of the Republic of Poland upholds the right to privacy, indicating that "everyone has the right to the protection of their private and family life, honour and good name and to decide on their personal life". The aforementioned embraces the right to informational autonomy of the individual, i.e. the right to protection of personal data. These issues are regulated in Article 51, which states that only on the basis of a legal act may an individual be obliged to disclose information concerning himself or herself. Furthermore, this constitutional provision contains the power of public authorities to obtain, collect and make available only such information as is necessary in a democratic state of law. The Constitution also defines the right of everyone to access 
official documents and data concerning him/her (only the act may limit such right) and to demand correction and removal of information being untrue, incomplete or collected in a manner contradictory with the Act. Articles 53(7) and 76 are also worth citing. The former states that "no one shall be obliged by public authorities to disclose their worldview, religious beliefs or creed" and the latter defines that "public authorities shall protect consumers, users and tenants against activities which endanger their health, privacy and safety and against unfair market practices".

In connection with the above mentioned, it should be pointed out that various elements of the right to privacy are regulated and specified in Articles 48-51, 53(7) and 76 of the Constitution, thus they constitute lex specialis in relation to Article 47.

\section{New technologies versus the right to privacy - selected issues}

In the current reality, the right to privacy comes down in particular to issues relating to widely understood protection of personal data. Interference into our private sphere today takes place predominantly through the collection and processing of data on individual units/persons. Various registers and databases had obviously functioned much earlier, but the progress and technological development that facilitated their creation, eliminatingfor example the necessity to manually enter the acquired data.

It is becoming increasingly apparent that regulations in force governing the right to privacy and the protection of personal data do not meet the requirements brought with technological development. Research shows that the popularisation of the Internet, in particular, is a huge threat, because information concerning us has become more accessible, and technological progress has made it possible not only to collect itmore efficiently but also to exchange, concentrate and associate them on a huge scale.

One of the greatest "threats" brought with the emergence of new technologies is the use of large-scale monitoring. All kinds of cameras have become a natural element of our world. Some of them are not even noticed, but taking a good look one may find cameras in neighbourhoods, on streets, in shops, in offices, in hotels or in airports. Moreover, one may also find them in schools, kindergartens or banks. This is how monitoring is used by public sector representatives to carry out tasks related to security or public order, but also representatives of the private sector, justifying the use of this tool by the need to control their employees but also to control their customers' behaviour. 
The development of the monitoring itself, as well as the scale of its use, has not resulted in the "development" of applicable legal regulations in this area. Therefore, the intensive development of this tool brings a reasonable threat to our privacy and thus gives rise to concern among citizens. In Polish reality, despite speeches by the Inspector General for Personal Data Protection (currently the President of the Office for Personal Data Protection) who pointed out that "video and audio-visual monitoring, used as a means of supporting the maintenance of security and order, arouses more and more controversy; it arises not only on the grounds of doubts as to the very fact of its application, but also of growing disproportions between the purpose it serves and the limitation of the right to privacy introduced by its application" and one made by the Ombudsman (the Speech from March 7, 2018), there is still a lack of legal solutions which would regulate the principles defining situations in which the installation of monitoring is justified, the number recordings to be stored and who may have access to them. Entry into force of the Regulation of the European Parliament and the Council (EU) of 27 April 2016 on the protection of individuals with regard to the processing of personal data and on the free movement of such data and the repeal of Directive 95/46/EC - General Data Protection Regulation (thereinafter RODO) has undoubtedly had a positive impact in this area. At the same time, there are also a number of provisions governing powers and the responsibilities of those who may carry out surveillance to ensure security (for example: art. 9a of the Act on municipal self-government 〈Dz.U. z 2018 r. poz. 994 i 1000); art. 4b of the the Act on poviat self-government 〈Dz.U. z 2018 r. poz. 995 i 1000 ; art. 60a of the Act on voivodeship self-government $\langle$ Dz.U. z 2018 r. poz. 913〉; art. 5a of the Act on the principles of managing state property 〈Dz.U. z 2016 r. poz. 2259〉; art. 15 and art. 19 of the Police Act 〈Dz.U. z 2017 r. poz. 2067); art. 20g of the Act on public roads 〈Dz.U. z 2017 r. poz. 2222); art. 11 of the Act on safety of mass events 〈Dz.U. z 2017 r. poz. 1160〉), but, irrespective of this fact, a systematic solution should be introduced.

Another problematic area related to the development of technology is, for example, the issue of collecting and recording data. Until a few years ago, there was no technology capable of analysing large amounts of data and extracting useful conclusions. Today, it is no secret that there are solutions in the form of automated algorithms, by means of which digital traces left by users can not only be collected, but also processed and undergo in-depth analysis. This analysis enables the search for patterns of behaviour and thus opens the door to an insight into our behaviour and private life. It is about 
the so-called "Big Data", which is nothing more than enormous collections of data created by people using the Internet, which can be stored, understood and used via special tools and methods. As A. De Mauro, M. Greco and M. Grimaldi point out, "Big Data is an information resource characteristic of such a large quantity, speed and diversity that they require specific technologies and analytical methods to convert them into value" (De Mauro, Greco, Grimaldi, 2016: 122-135). In such a massive collection, a variety of data can undergo analysis, for example satellite images of the site, personal data, pictures of people, addresses, GPS routes, IP addresses, information posted on social networks.

Thus, when individual categories of data are analysed, the risk of privacy violations is relatively less, but the compilation and analysis of all the categories together may significantly threaten the privacy right. The European Parliament's resolution of 2017 (P8_TA-PROV(2017)0076, Strasbourg, 14 March 2017) indicates that the prospects and opportunities of large data collections can only be used when strong enforcement of fundamental rights guarantees public confidence in these technologies. The threats in question may, for example, consist in obtaining informed consent for data processing, identifying the actual controller and the person processing the data, and thus establishing liability for possible infringements.

\section{Final conclusions}

Various tools brought with technological development, which may create or intensify the threat of violation of the right to privacy, can be multiplied. The two examples mentioned above already give rise to controversy.

Monitoring and its increasing spread may lead to such violations of the private sphere as, e.g., the phenomenon of surveillance. Consequently, it may also result in recordings shared and available on the Internet or passed on to the media. It may soon be the case that we will only be free from cameras in our own homes. Is then privacy even possible? One of the most prominent cases in this area was the complaint by Peck v. United Kingdom before the European Court of Human Rights in 2003 (complaint nr 44647/98, judgment on 28 January 2003). The case concerned a media leakage of a video recorded by monitoring cameras showing a suicide attempt. The Court ruled that Article 8 of the ECHR had been infringed, indicating that the essence of the infringement of the right to privacy in this case was not the presence of the monitoring itself, but the improper way in which the recordings were stored and secured. 
With regard to "Big Data", the danger lies in the possibility of collecting detailed data about a particular person as a result of analysing a set of many different types of data. By combining this information, a detailed image of the person concerned may come to light, and this may be used in an inappropriate way. For example, the collection of detailed information about a person's state of health may influence, for example, the price of life insurance offered.

Unfortunately, the reality no longer guarantees keeping everything that we want or need solely to ourselves - in our private sphere. It is important to realise that we do not really have full control over the above, and the law that should protect us from such violations - also proves powerless in most cases.

\section{R E F E R E N C E S}

Altman, I. (1975). The Environment and Social Behavior: Privacy, Personal Space, Territory, Crowding. Brooks/Cole Publishing Company.

Altman, I. (1975). Privacy Regulation: Culturally Universal or Culturally Specific? The Journal of Social Issues, 33 (3), 66-84.

Bloustein, E. J. (1964). Privacy as an Aspect of Human Dignity: An Answer to Dean Prosser. New York University Law Review, 39, 962-1007.

De Mauro, A., Greco, M., Grimaldi, M. (2016). A formal definition of Big Data based on its essential features. Library Review, Vol. 65, Issue 3, 122-135.

Fried, C. (1970). Privacy (A Moral Analysis). Yale Law Journal, 77(1), 475-493.

Fried, C. (1970). An Anatomy of Values. Cambridge: Harvard University Press.

Mednis, A. (2006). Prawo do prywatności a interes publiczny. Wolters Kluwer.

Jagielski, M. (2010). Prawo do ochrony danych osobowych. Standardy europejskie. Wolters Kluwer.

O'Connor, S.C., Rosenblood, L.K. (1996). Affiliation motivation in everyday experience: A theoretical comparison. Journal of Personality and Social Psychology, 70(3), 513-522.

Parent, W.A. (1983). Privacy, Morality, and the Law. Philosophy and Public Affairs, 12 (4), 269-288.

Schoeman, F.D. (1984). Philosophical Dimensions of Privacy: An Anthology. Cambridge-London-New York-New Rochelle-Melbourne-Sydney.

Schoeman, F.D. (1992). Privacy and Social Freedom. Cambridge University Press.

Warren, S., Brandeis, L. (1890). The Right to Privacy. Harvard Law Review, 4(1), 193-220.

Weber, M.J. (2004). Naruszanie prywatności. Wielki brat i korporacyjni hakerzy. Warszawa. 
Zaleski, Z. (2001). Prawo do prywatności - aspekty psychologiczne. In Motyka K. (Eds.), Prawo do prywatności. Aspekty prawne i psychologiczne. Lublin.

Report of the Panoptykon Foundation "Supervision 2011", https://panoptykon.org/ sites/default/files/raport_nadzor.pdf (access 7.08.2020).

Report "Privacy on the Web 2016/2017", https://www.iab.org.pl/wp-content/ uploads/2017/03/IAB_Polska_Prywatnosc_w_sieci_2016_2017_raport.pdf (access 7.08.2020).

The Speech of the Ombudsman from March $7^{\text {th }}, 2018$, https://www.rpo.gov.pl/ sites/default/files/Wystąpienie\%20do\%20MSWiA\%20ws.\%20monitoringu.pdf (access 7.08.2020). 